\title{
First-in-human Phase I study of EZN-4176, a locked nucleic acid antisense oligonucleotide to exon 4 of the androgen receptor mRNA in patients with castration-resistant
} prostate cancer

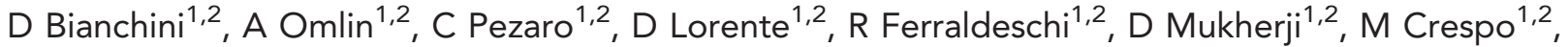

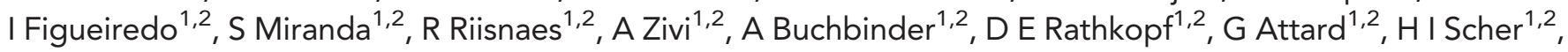
J de Bono*,1,2,3,4 and D C Danila ${ }^{1,2,3,4}$

${ }^{1}$ Prostate Cancer Targeted Therapy Group and Drug Development Unit, Royal Marsden NHS Foundation Trust and The Institute of Cancer Research, Downs Road, Sutton, Surrey, UK; ${ }^{2}$ Memorial Sloan-Kettering Cancer Center (MSKCC) and Weill Cornell Medical College, Center for Prostate and Urologic Cancers, New York, NY, USA and ${ }^{3}$ ENZON Pharmaceuticals Inc.; Bridgewater, NJ, USA
\end{abstract}

Background: Prostate cancer remains dependent of androgen receptor (AR) signalling, even after emergence of castration resistance. EZN-4176 is a third-generation antisense oligonucleotide that binds to the hinge region (exon 4) of AR mRNA resulting in full-length AR mRNA degradation and decreased AR protein expression. This Phase I study aimed to evaluate EZN-4176 in men with castration-resistant prostate cancer (CRPC).

Methods: Patients with progressing CRPC were eligible; prior abiraterone and enzalutamide treatment were allowed. EZN-4176 was administered as a weekly (OW) 1-h intravenous infusion. The starting dose was $0.5 \mathrm{mg} \mathrm{kg}^{-1}$ with a 4-week dose-limiting toxicity (DLT) period and a $3+3$ modified Fibonacci dose escalation design. After determination of the DLT for weekly administration, an every 2 weeks schedule was initiated.

Results: A total of 22 patients were treated with EZN-4176. At $10 \mathrm{mg} \mathrm{kg}^{-1} \mathrm{OW}$, two DLTs were observed due to grade 3-4 ALT or AST elevation. No confirmed biochemical or soft tissue responses were observed. Of eight patients with $\geqslant 5$ circulating tumour cells at baseline, a conversion to $<5$ was observed in three (38\%) patients. The most common EZN-4176-related toxicities (all grades) were fatigue (59\%), reversible abnormalities in liver function tests ALT (41\%) and AST (41\%) and infusion-related reactions including chills (36\%) and pyrexia (14\%).

Conclusion: Activity of EZN-4176 at the doses and schedules explored was minimal. The highest dose of $10 \mathrm{mg} \mathrm{kg}^{-1} \mathrm{OW}$ was associated with significant but reversible transaminase elevation.

Advanced prostate cancer that is no longer controlled by medical or surgical castration (castration-resistant prostate cancer, CRPC) remains dependent on signalling through the androgen receptor
(AR) (Attard et al, 2011). Proposed mechanisms to explain AR reactivation include intratumoural androgen production, overexpression of $\mathrm{AR}$ and development of $\mathrm{AR}$ mutants with

*Correspondence: Professor J de Bono; E-mail: johann.de-bono@icr.ac.uk

${ }^{4}$ Co-senior authors.

Received 25 July 2013; revised 12 September 2013; accepted 15 September 2013; published online 29 October 2013

(c) 2013 Cancer Research UK. All rights reserved 0007-0920/13 
promiscuous or constitutive activity (Linja et al, 2001; Montgomery et al, 2008; Guo et al, 2009; Richards et al, 2012). The survival improvements resulting from novel androgentargeting therapies such as abiraterone and enzalutamide have confirmed the value of further targeting of AR in CRPC (de Bono et al, 2011; Scher et al, 2012; Ryan et al, 2013). However, these drugs are not designed to eliminate AR and resistance to both agents invariably occurs. Progression is usually accompanied by rising PSA, suggesting resumption of AR signalling. Agents with the ability to down-modulate $\mathrm{AR}$ therefore offer an attractive therapeutic prospect.

Antisense therapies involve the use of single-stranded oligonucleotides to induce RNA degradation (Vidal et al, 2005). Thirdgeneration antisense oligonucleotides (ASOs) such as EZN-4176, EZN-2968 or EZN-3042 utilise a locked structure to improve the binding affinity for messenger RNA (mRNA) and reduce oligonucleotide length (Gleave and Monia, 2005). ASOs specifically bind to the complementary region of mRNA, leading to enzymatic destruction of mRNA and ultimately to reduction in protein expression. EZN-4176 is a locked nucleic acid (LNA) ASO designed as a specific AR mRNA antagonist. EZN-4176 binds exon 4 in the hinge region of the AR mRNA and downregulates full-length $A R$ and some AR splice variants (AR-V7, AR-V12, AR-V13 and V14) (Dehm and Tindall, 2011). Down-modulation of AR mRNA was demonstrated in vitro in androgen-sensitive and CRPC cell lines and animal models (Zhang et al, 2011). Preclinical toxicology studies suggested EZN-4176 tissue deposition in the liver, kidneys and heart and transient complement activation and recommended a starting dose for human studies of $0.5 \mathrm{mg} \mathrm{kg}^{-1}$ administered as a weekly intravenous infusion.

The aim of this Phase I study was to establish the safety, tolerability, preliminary efficacy, maximum tolerated dose (MTD) and schedule of EZN-4176 in men with progressive CRPC.

\section{PATIENTS AND METHODS}

EZN-4176. EZN-4176 is composed of 16 monomeric units, a 16-mer, of which six DNA nucleotides have been replaced with LNA nucleotides. The sequence of the molecule is as follows: 5'-ACCaagtttcttcAGC-3', where capital letters denote LNA monomers and lower case letters denote DNA monomers. EZN-4176 is a fully phosphorothioated oligonucleotide complementary to the target residues.

Patients. Castrate patients with histologically or cytologically proven metastatic prostate adenocarcinoma, progressive disease as defined by the Prostate Cancer Working Group 2 Criteria (PCWG2) (Scher et al, 2008), an Eastern Cooperative Oncology Group performance status (ECOG PS) of $0-1$ and adequate hematopoietic, hepatic and renal function were eligible for the study. The minimum required washout period was 4 weeks after radiotherapy (2 weeks after single-fraction), chemotherapy, immunotherapy or any other anticancer therapy (6 weeks for mitomycin $\mathrm{C}$ or nitrosureas). Patients receiving stable doses of bisphosphonates before enrolment were eligible; however, initiation or modification of bisphosphonates was not permitted while on study. Patients with brain metastases, spinal cord compression, chronic infectious diseases or serious concurrent medical illnesses were excluded. Patients receiving $>10 \mathrm{mg}$ per day of prednisolone or equivalent systemic corticosteroids or concomitant anticoagulant therapy were also excluded.

Study design. This was a Phase $\mathrm{Ia} / \mathrm{Ib}$, open label, dose-escalation study conducted at two institutions (Royal Marsden NHS Foundation Trust and The Institute of Cancer Research (RM), Sutton, United Kingdom and Memorial Sloan-Kettering Cancer Centre (MSKCC), New York, United States of America).
The primary objectives of this study were to determine the MTD of EZN-4176 and to recommend a phase II dose and schedule. Secondary objectives included the evaluation of safety, tolerability, pharmacokinetic (PK) and pharmacodynamic (PD) profiling of EZN-4176, preliminary evidence of antitumour activity and an exploratory analysis of predictive biomarkers of resistance or response.

The study consisted of a dose-escalation phase (phase Ia) to determine the MTD and a cohort expansion phase (phase Ib) at one or more dose levels to determine the recommended phase II dose and schedule.

The MTD was defined as the maximum dose of EZN-4176 at which no more than 1 out of 6 patients presented a dose-limiting toxicity (DLT). The following were defined as DLTs: febrile neutropenia, asymptomatic grade 4 neutropenia or thrombocytopenia, grade 3 thrombocytopenia with bleeding and grade 3-4 nonhaematologic toxicities except transient $(<24 \mathrm{~h})$ changes in liver function tests or electrolyte levels, occurring within the first 4 -week cycle. Toxicities that resulted in a $>15$-day delay in treatment administration were also considered DLTs. Dose escalation followed a $3+3$ modified Fibonacci dose-escalation design. Ten dose escalation cohorts were planned. Intrapatient dose escalation was allowed after 6 months in the absence of disease progression, provided that a response had been observed in the higher-dose cohort and that the higher dose had been declared safe and tolerable.

\begin{tabular}{|c|c|c|}
\hline & $\mathbf{N}=\mathbf{2 2}$ & $\%$ \\
\hline \multicolumn{3}{|l|}{ Age (years) } \\
\hline $\begin{array}{l}\text { Median } \\
\text { Range }\end{array}$ & $\begin{array}{c}71 \\
59-84\end{array}$ & \\
\hline \multicolumn{3}{|l|}{ Race } \\
\hline White & 22 & $100 \%$ \\
\hline \multicolumn{3}{|l|}{ ECOG PS } \\
\hline $\begin{array}{l}0 \\
1\end{array}$ & $\begin{array}{r}6 \\
16\end{array}$ & $\begin{array}{l}27.3 \% \\
72.7 \%\end{array}$ \\
\hline \multicolumn{3}{|l|}{ Gleason score } \\
\hline $\begin{array}{l}\geqslant 8 \\
7 \\
\leqslant 6 \\
N A\end{array}$ & $\begin{array}{r}12 \\
5 \\
3 \\
2\end{array}$ & $\begin{array}{l}54.5 \% \\
22.7 \% \\
13.6 \% \\
9.0 \%\end{array}$ \\
\hline \multicolumn{3}{|l|}{ Metastatic sites } \\
\hline $\begin{array}{l}\text { Bone } \\
\text { Lymph node } \\
\text { Visceral }\end{array}$ & $\begin{array}{r}18 \\
17 \\
7\end{array}$ & $\begin{array}{l}82 \% \\
77 \% \\
32 \%\end{array}$ \\
\hline \multicolumn{3}{|l|}{ Prior treatment } \\
\hline $\begin{array}{l}\text { Antiandrogen } \\
\text { LHRH analogue or antagonist } \\
\text { Docetaxel } \\
\text { Corticosteroids } \\
\text { Ketoconazole } \\
\text { Abiraterone } \\
\text { Other cytotoxics }\end{array}$ & $\begin{array}{r}22 \\
22 \\
8 \\
8 \\
4 \\
3 \\
5\end{array}$ & $\begin{array}{l}100 \% \\
100 \% \\
36.3 \% \\
36.3 \% \\
18.2 \% \\
13.6 \% \\
22.7 \%\end{array}$ \\
\hline \multicolumn{3}{|c|}{$\begin{array}{l}\text { Abbreviations: ECOG PS = Eastern Cooperative Oncology Group Performance status; } \\
\text { LHRH = luteinizing-hormone-releasing hormone; } N A=\text { not applicable. Other cytotoxic } \\
\text { treatments: vinblastine }(n=1) \text {, tesetaxel }(n=1) \text {, cabazitaxel }(n=2) \text {, taxol and carboplatin } \\
(n=1) \text {. }\end{array}$} \\
\hline
\end{tabular}


The study was approved by the ethics review committees of the RM and MSKCC, in accordance with the Principle of Declaration of Helsinki and International Conference on Harmonization Good Clinical Practice Guidelines. Written informed consent was obtained from all patients.

Procedures. Medical history and demographic data were collected at baseline. Safety evaluations were conducted at baseline and on infusion days, including clinical evaluation (including ECOG PS, adverse events (AEs) and toxicity assessment, physical exam and vital signs), laboratory tests (including full blood count, biochemistry, urinalysis and coagulation panel) and a 12-lead ECG (at cycle 1 , day 1 and repeated during the study if clinically indicated). Adverse events were graded according to the National Cancer Institute Common Terminology Criteria for Adverse Events, Version 4.0.

Treatment response assessment was performed according to the PCWG2 with computed tomography and bone scans repeated every 12 weeks. The levels of PSA were determined pre-dose on day 1 , every 2 weeks (from cycle 1 to 3 ), on day 1 (pre-dose) for subsequent cycles and at the end-of-study visit. In the patients treated at RM, blood samples for circulating tumour cell (CTC) enumeration were collected before the first administration of EZN-4176, every 4 weeks on study and at the final visit.

Pharmacokinetics/pharmacodynamics. Blood samples for determination of the PK of EZN-4176 were collected for cycle 1 day 1 pre-dose (within $4 \mathrm{~h}$ of the infusion); $30 \mathrm{~min}$ after the start of infusion; 5 min before the end of infusion; 0.5, 1, 3, 5, 24, 48 and $72 \mathrm{~h}$ after the end of infusion; and before administration of the next scheduled dose of EZN-4176. Thereafter, pre-dose PK blood samples were collected every 4 weeks and at the end-of-study visit. PK parameter estimations were computed from individual plasma concentrations applying a non-compartmental approach using appropriate validated PK software (Phoenix Copyright 2012, Pharsight Corporation, St Louis, MO, USA). The PK parameters were summarised by dose level using descriptive statistics, including mean, standard deviation and coefficient of variation. Dose proportionality of EZN-4176 was explored by analysing $\mathrm{PK}$ variables of $\mathrm{AUC}_{0-\mathrm{t}}, \mathrm{AUC}_{0-\infty}$ and maximum concentration $\left(\mathrm{C}_{\max }\right)$.
Fresh tumour biopsies before and after EZN-4176 administration were optional until determination of the MTD. Tumour biopsies were performed within 21 days before the first infusion of EZN-4176 and within $48 \mathrm{~h}$ after the end of the third infusion of EZN-4176. The PD effects of EZN-4176 were assessed based on AR expression in tumour biopsies by immunohistochemistry using antibodies directed against two distinct regions of the AR; the N-terminal (Dako (Glostrup, Denmark), clone AR441) and C-terminal of AR protein (Abcam (Cambridge, UK), AR clone EP670Y).

\section{RESULTS}

Patient characteristics. Between April 2011 and September 2012 a total of 23 patients signed the informed consent and 22 received at least one dose of EZN-4176. One patient presented with raised liver function tests in multiple assessments after signing consent and therefore was deemed not suitable for study participation.

The median age of participants was 71 years (range 59-84) (Table 1). All the patients were metastatic at enrolment with bone $(n=18,82 \%)$ and nodal disease $(n=17,77 \%)$ being the most represented sites of metastases. The majority of patients $(72.7 \%)$ had ECOG PS 1. Eight patients (36\%) had received prior docetaxel and three $(14 \%)$ were pretreated with abiraterone.

Dose escalation and DLT. EZN-4176 was administered initially as a 1-h intravenous weekly infusion (QW) in 4 weekly cycles. The dose schedule was modified to an every two weeks (Q2W) schedule due to asymptomatic transaminase elevation. Dose levels evaluated were $0.5,1,2,4,6.5$ and $10 \mathrm{mg} \mathrm{kg}^{-1} \mathrm{QW} ; 10 \mathrm{mg} \mathrm{kg}^{-1}$ was also administered on the Q2W schedule. Patients received a median of 10 doses of EZN-4176 (range 3-20) on study.

Two DLTs were observed at $10 \mathrm{mg} \mathrm{kg}^{-1}$ weekly infusion due to reversible grade 3 or 4 ALT or AST rise without concurrent bilirubin elevation. In both patients the abnormal liver function tests completely resolved without intervention. One patient had grade 3 increased ALT and grade 2 increased AST. This patient received EZN-4176 on weeks 1 and 3, having missed the week 2 dose due to a chest infection resulting in general deterioration. The second patient developed grade 4 increased ALT and

Table 2. Treatment-related adverse events occurring in at least $10 \%$ of patients overall

\begin{tabular}{|c|c|c|c|c|c|c|c|c|c|c|c|c|c|c|c|c|}
\hline \multirow{2}{*}{$\begin{array}{l}\begin{array}{l}\mathrm{AE} \\
\text { term }\end{array} \\
\mathrm{N}(\%)\end{array}$} & \multicolumn{2}{|c|}{$\begin{array}{l}\text { Cohort A } \\
0.5 \mathrm{mg} \mathrm{kg}^{-1} \\
(N=3)\end{array}$} & \multicolumn{2}{|c|}{$\begin{array}{c}\text { Cohort B } \\
1 \mathrm{mg} \mathrm{kg}^{-1} \\
(\mathbf{N}=3)\end{array}$} & \multicolumn{2}{|c|}{$\begin{array}{c}\text { Cohort C } \\
2 \mathrm{mg} \mathrm{kg}^{-1} \\
(\boldsymbol{N}=3)\end{array}$} & \multicolumn{2}{|c|}{$\begin{array}{c}\text { Cohort D } \\
4 \mathrm{mg} \mathrm{kg}^{-1} \\
(\mathbf{N}=3)\end{array}$} & \multicolumn{2}{|c|}{$\begin{array}{l}\text { Cohort E } \\
6.5 \mathrm{mg} \mathrm{kg}^{-1} \\
(N=3)\end{array}$} & \multicolumn{2}{|c|}{$\begin{array}{l}\text { Cohort F } \\
10 \mathrm{mg} \mathrm{kg}^{-1} \\
(\mathbf{N}=6)\end{array}$} & \multicolumn{2}{|c|}{$\begin{array}{c}\text { Cohort F2 } \\
10 \mathrm{mg} \mathrm{kg}^{-1} \\
\text { Q2W }(\mathbf{N}=1)\end{array}$} & \multicolumn{2}{|c|}{$\begin{array}{c}\text { All } \\
(N=22)\end{array}$} \\
\hline & $\begin{array}{c}\text { All } \\
\text { grades }\end{array}$ & $\begin{array}{c}\text { Grade } \\
\geqslant 3\end{array}$ & $\begin{array}{c}\text { All } \\
\text { grades }\end{array}$ & $\begin{array}{c}\text { Grade } \\
\geqslant 3\end{array}$ & $\begin{array}{c}\text { All } \\
\text { grades }\end{array}$ & $\begin{array}{c}\text { Grade } \\
\geqslant 3\end{array}$ & $\begin{array}{c}\text { All } \\
\text { grades }\end{array}$ & $\begin{array}{c}\text { Grade } \\
\geqslant 3\end{array}$ & $\begin{array}{c}\text { All } \\
\text { grades }\end{array}$ & $\begin{array}{c}\text { Grade } \\
\geqslant 3\end{array}$ & $\begin{array}{c}\text { All } \\
\text { grades }\end{array}$ & $\begin{array}{c}\text { Grade } \\
\geqslant 3\end{array}$ & $\begin{array}{c}\text { All } \\
\text { grades }\end{array}$ & $\begin{array}{c}\text { Grade } \\
\geqslant 3\end{array}$ & $\begin{array}{c}\text { All } \\
\text { grades }\end{array}$ & $\begin{array}{c}\text { Grade } \\
\geqslant 3\end{array}$ \\
\hline Fatigue & 1 (33) & 0 & $2(67)$ & 0 & 0 & 0 & $2(67)$ & 0 & $2(67)$ & 0 & $5(83)$ & 0 & $1(100)$ & 0 & $13(59)$ & 0 \\
\hline Chills & 0 & 0 & 0 & 0 & 0 & 0 & 0 & 0 & $3(100)$ & 0 & $4(67)$ & 0 & $1(100)$ & 0 & $8(36)$ & 0 \\
\hline Pyrexia & 0 & 0 & 0 & 0 & 0 & 0 & 0 & 0 & 0 & 0 & $3(50)$ & 0 & 0 & 0 & $3(14)$ & 0 \\
\hline Nausea & $1(33)$ & 0 & $1(33)$ & 0 & 0 & 0 & $1(33)$ & 0 & $2(67)$ & 0 & $3(50)$ & & 0 & 0 & $8(36)$ & 0 \\
\hline $\begin{array}{l}\text { Consti- } \\
\text { pation }\end{array}$ & $1(33)$ & 0 & $1(33)$ & 0 & 0 & 0 & 1 (33) & 0 & 0 & 0 & 1 (17) & & 0 & 0 & $4(18)$ & 0 \\
\hline Anorexia & 1 (33) & 0 & 1 (33) & 0 & 0 & 0 & 1 (33) & 0 & 0 & 0 & 1 (17) & & 0 & 0 & $4(18)$ & 0 \\
\hline Dyspepsia & 0 & 0 & 0 & 0 & 1 (33) & 0 & 0 & 0 & 0 & 0 & $3(50)$ & & 0 & 0 & $4(18)$ & 0 \\
\hline Diarrhoea & $1(33)$ & 0 & 0 & 0 & 0 & 0 & 0 & 0 & 0 & 0 & $2(33)$ & & 0 & 0 & $3(14)$ & 0 \\
\hline ALT & 0 & 0 & 0 & 0 & 0 & 0 & 0 & 0 & $3(33)$ & $1(33)$ & $5(83)$ & $4(67)$ & $1(100)$ & 0 & $9(41)$ & $5(23)$ \\
\hline AST & 0 & 0 & 0 & 0 & 0 & 0 & 0 & 0 & $3(33)$ & 1 (33) & $5(83)$ & $3(50)$ & $1(100)$ & 0 & $9(41)$ & $4(18)$ \\
\hline
\end{tabular}


grade 3 increased AST after the third QW infusion. Therefore, $10 \mathrm{mg} \mathrm{kg}^{-1}$ was determined to exceed the MTD when EZN-4176 was administered QW as well as for a 3 out of 4 -week schedule. No DLTs were reported in the $6.5 \mathrm{mg} \mathrm{kg}^{-1}$ cohort but the study was terminated before expansion for MTD evaluation. One patient initiated treatment with Q2W EZN-4176 before the study was terminated, and this patient had no DLTs.

\section{Safety and tolerability}

Adverse events. EZN-4176 was overall well tolerated with the most common side effects being fatigue, infusion-related reactions and transaminase elevations. Twenty-one (95\%) patients reported at least one AE during the study. Three patients (one in the $6.5 \mathrm{mg} \mathrm{kg}^{-1}$ and two in the $10 \mathrm{mg} \mathrm{kg}^{-1}$ QW dose levels) had a dose reduction. Adverse events considered by the investigator to be related to EZN-4176 were reported for 17 (77\%) patients. Five patients (23\%) reported at least one drug-related AE that was grade 3 or 4 (Table 2). No deaths were reported during the study. Seven (32\%) patients reported at least one SAE, none of which were considered treatment-related. Three (14\%) patients had an AE that led to discontinuation of study treatment; one of these patients had treatment-related AEs (increased liver ALT and AST) that led to discontinuation of study treatment.
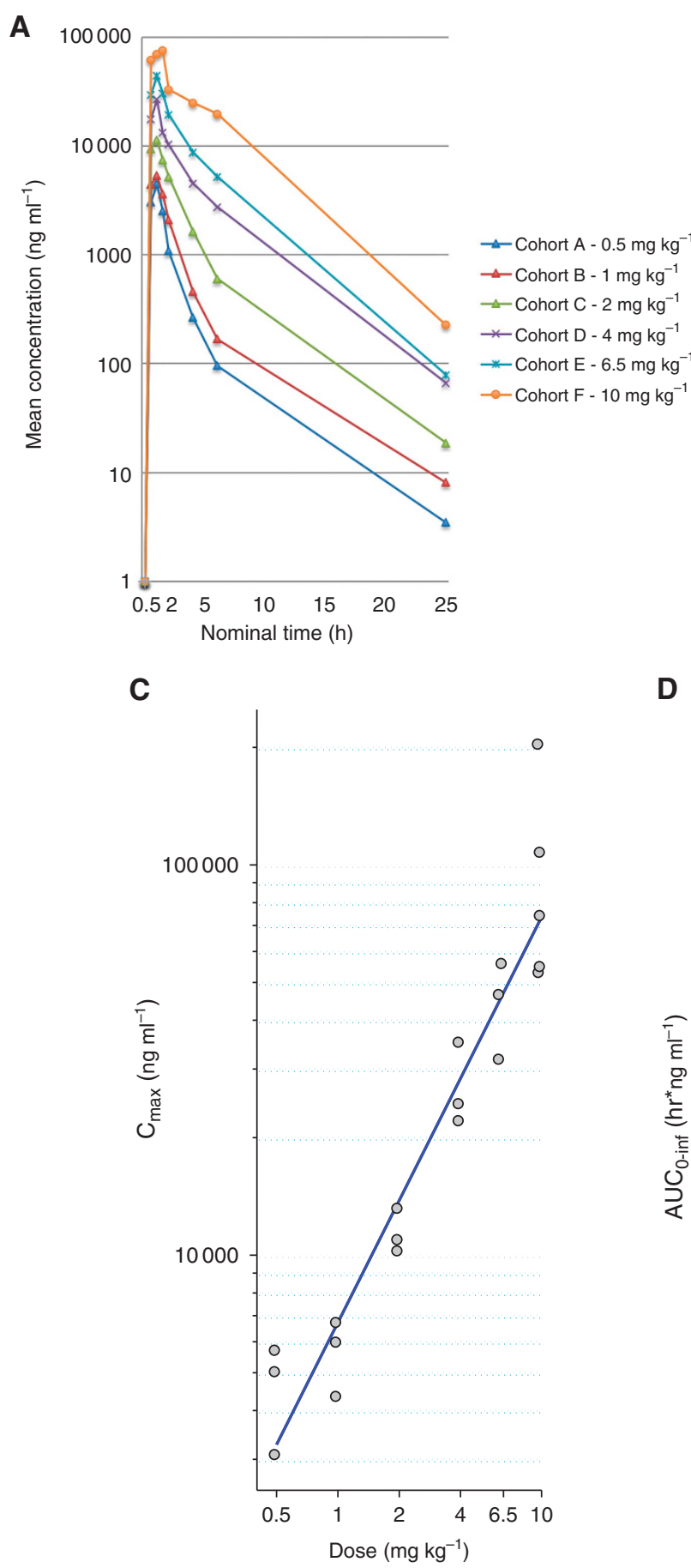

B

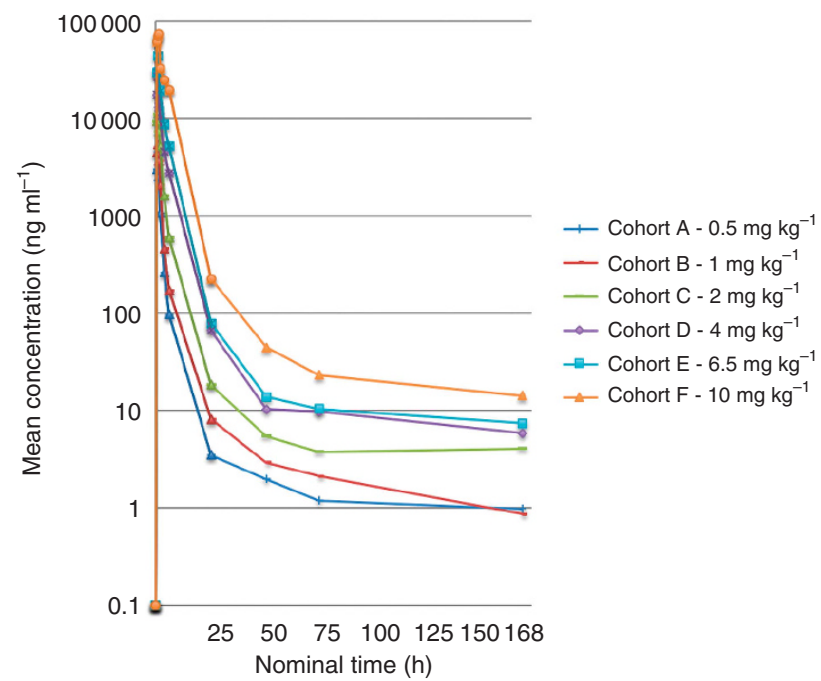

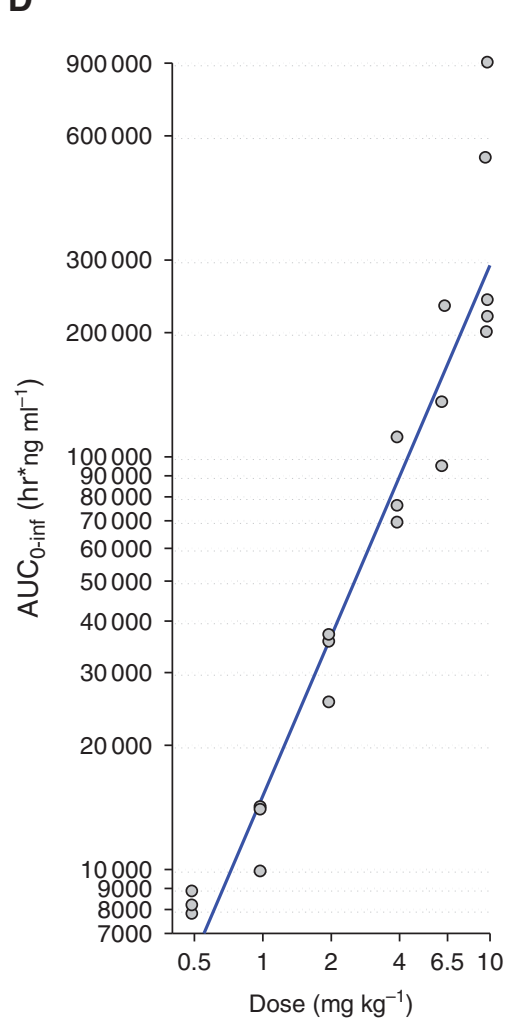

Figure 1. Pharmacokinetics of ENZ-4176. Each colour line represents mean plasma EZN-4176 levels (linear scale) along the initial (A) 25 and (B) $168 \mathrm{~h}$ after the first infusion for the different dose-escalation levels. Dose (mg) vs (C) $C_{\max }\left(\mathrm{ng} \mathrm{ml}^{-1}\right)$ and (D) $\mathrm{AUC}_{0-\infty}\left(\mathrm{ng} \mathrm{h} \mathrm{ml}^{-1}\right)$ (log-log scale). Both $\mathrm{C}_{\max }$ and $\mathrm{AUC}_{0-\infty}$ increased with dose. 


\begin{tabular}{|c|c|c|c|c|c|c|c|}
\hline Cohort & $\begin{array}{l}t_{1 / 2} \\
(h)\end{array}$ & $\begin{array}{c}\mathrm{C}_{\max } \\
\left(\mathrm{ng} \mathrm{ml}^{-1}\right)\end{array}$ & $\begin{array}{c}\text { AUC }_{0-72} \\
\left(\mathrm{~h} \mathrm{ng} \mathrm{ml}^{-1}\right)\end{array}$ & $\begin{array}{c}\text { AUC }_{0-\mathrm{t}} \\
\left(\mathrm{hrng} \mathrm{ml}{ }^{-1}\right)\end{array}$ & $\begin{array}{c}\text { AUC }_{0-\infty} \\
\left(\mathrm{hrng} \mathrm{ml}{ }^{-1}\right)\end{array}$ & $\begin{array}{c}\mathrm{Cl} \\
\left(\mathrm{ml} \mathrm{hr}^{-1} \mathrm{~kg}^{-1}\right)\end{array}$ & $\begin{array}{c}\mathrm{V}_{\mathrm{ss}} \\
\left(\mathrm{ml} \mathrm{kg}^{-1}\right)\end{array}$ \\
\hline \multicolumn{8}{|c|}{ Cohort A $0.5 \mathrm{mg} \mathrm{kg}^{-1}$} \\
\hline Mean & 54.8 & 4540 & 8060 & 8110 & 8180 & 61.3 & 296 \\
\hline $\begin{array}{l}\text { s.d. } \\
\text { cv\% }\end{array}$ & $\begin{array}{l}33.7 \\
61.5\end{array}$ & $\begin{array}{l}1340 \\
29.6\end{array}$ & $\begin{array}{l}622 \\
7.71\end{array}$ & $\begin{array}{l}558 \\
6.88\end{array}$ & $\begin{array}{l}518 \\
6.33\end{array}$ & $\begin{array}{l}3.83 \\
6.25\end{array}$ & $\begin{array}{l}275 \\
92.7\end{array}$ \\
\hline \multicolumn{8}{|c|}{ Cohort B $1 \mathrm{mg} \mathrm{kg}^{-1}$} \\
\hline Mean & 82.5 & 5600 & 12300 & 12400 & 12500 & 82.1 & 518 \\
\hline $\begin{array}{l}\text { s.d. } \\
\text { cv\% }\end{array}$ & $\begin{array}{c}70.1 \\
85\end{array}$ & $\begin{array}{l}1190 \\
21.3\end{array}$ & $\begin{array}{l}2420 \\
19.7\end{array}$ & $\begin{array}{l}2430 \\
19.6\end{array}$ & $\begin{array}{l}2390 \\
19.1\end{array}$ & $\begin{array}{l}17.6 \\
21.4\end{array}$ & $\begin{array}{l}369 \\
71.2\end{array}$ \\
\hline \multicolumn{8}{|c|}{ Cohort C $2 \mathrm{mg} \mathrm{kg}^{-1}$} \\
\hline Mean & 221 & 11300 & 30700 & 31000 & 32300 & 63.8 & 1820 \\
\hline $\begin{array}{l}\text { s.d. } \\
\text { CV\% }\end{array}$ & $\begin{array}{c}126 \\
57.3\end{array}$ & $\begin{array}{l}1490 \\
13.2\end{array}$ & $\begin{array}{l}6420 \\
20.9\end{array}$ & $\begin{array}{l}6490 \\
20.9\end{array}$ & $\begin{array}{l}6270 \\
19.4\end{array}$ & $\begin{array}{l}13.9 \\
21.8\end{array}$ & $\begin{array}{l}1620 \\
89.1\end{array}$ \\
\hline \multicolumn{8}{|c|}{ Cohort D $4 \mathrm{mg} \mathrm{kg}^{-1}$} \\
\hline Mean & 63.6 & 26900 & 83300 & 84000 & 84600 & 49.3 & 281 \\
\hline $\begin{array}{l}\text { s.d. } \\
\text { CV\% }\end{array}$ & $\begin{array}{l}13.8 \\
21.7\end{array}$ & $\begin{array}{l}6820 \\
25.4\end{array}$ & $\begin{array}{c}21900 \\
26.3\end{array}$ & $\begin{array}{c}22100 \\
26.3\end{array}$ & $\begin{array}{c}22400 \\
26.5\end{array}$ & $\begin{array}{l}11.6 \\
23.5\end{array}$ & $\begin{array}{c}56.1 \\
20\end{array}$ \\
\hline \multicolumn{8}{|c|}{ Cohort E $6.5 \mathrm{mg} \mathrm{kg}^{-1}$} \\
\hline Mean & 55.8 & 44100 & 151000 & 151000 & 152000 & 48.8 & 244 \\
\hline $\begin{array}{l}\text { s.d. } \\
\text { CV\% }\end{array}$ & $\begin{array}{l}20.4 \\
36.6\end{array}$ & $\begin{array}{c}12000 \\
27.2\end{array}$ & $\begin{array}{c}69200 \\
45.9\end{array}$ & $\begin{array}{c}69200 \\
45.7\end{array}$ & $\begin{array}{c}69300 \\
45.6\end{array}$ & $\begin{array}{c}20.5 \\
42\end{array}$ & $\begin{array}{c}103 \\
42.4\end{array}$ \\
\hline \multicolumn{8}{|c|}{ Cohort F $10 \mathrm{mg} \mathrm{kg}^{-1}$} \\
\hline Mean & 86.2 & 97300 & 409000 & 411000 & 413000 & 33.9 & 249 \\
\hline $\begin{array}{l}\text { s.d. } \\
\text { Cv\% }\end{array}$ & $\begin{array}{l}32.9 \\
38.2\end{array}$ & $\begin{array}{c}61800 \\
63.5\end{array}$ & $\begin{array}{c}299000 \\
73\end{array}$ & $\begin{array}{c}299000 \\
72.7\end{array}$ & $\begin{array}{c}299000 \\
72.3\end{array}$ & $\begin{array}{l}17.5 \\
51.8\end{array}$ & $\begin{array}{l}181 \\
72.9\end{array}$ \\
\hline
\end{tabular}

Drug-related toxicities that occurred in more than $10 \%$ of patients are summarised in Table 2. Overall, the most common all-grades AEs considered to be related to EZN-4126 were fatigue $(n=13,59 \%)$, increased ALT and increased AST $(n=9,41 \%$ each), nausea and chills $(n=8,36 \%$ each). Increased ALT, increased AST and chills were reported at the higher dose levels only (above $4 \mathrm{mg} \mathrm{kg}^{-1}$ ). The most common grade 3-4 AEs were increased $\operatorname{ALT}(n=5,23 \%)$ and increased AST $(n=4,18 \%)$, all considered related to EZN-4176. These ALT and AST elevations were reversible and occurred without concurrent elevation of bilirubin. There were no events of cytokine release syndrome reported.

Pharmacokinetics. Plasma concentrations following the first infusion of EZN-4176 are shown in Figure 1 and Table 3. The maximum concentration $\left(\mathrm{C}_{\max }\right)$ ranged from $4540 \mathrm{ng} \mathrm{ml}^{-1}$ at $0.5 \mathrm{mg} \mathrm{kg}^{-1}$ to $97300 \mathrm{ng} \mathrm{ml}^{-1}$ at $10 \mathrm{mg} \mathrm{kg}^{-1}$ (Table 3). The PK parameters appeared to be broadly dose proportional (Figure 1).

\section{Pharmacodynamics}

AR modulation. Assessment of the $\mathrm{N}$ - and C-terminals of $\mathrm{AR}$ protein in tissue obtained before and after the third administration of EZN-4176 was performed for one patient $24 \mathrm{~h}$ post dose on cycle 1 day 16. An additional patient had a biopsy after the sixth administration of EZN-4176 but no tumour was present in the sample. No significant down-modulation of the AR protein was observed.

Response evaluation. All patients had discontinued treatment at the time of the analysis (11 February 2013) due to objective disease progression $(n=16,73 \%)$, investigator decision $(n=5,23 \%$ with four of them having progressed clinically or by PSA) and consent withdrawal $(n=1,4.5 \%)$.

One patient in the $2 \mathrm{mg} \mathrm{kg}^{-1}$ cohort had a $\geqslant 50 \%$ decrease in PSA at the time of discontinuation from EZN-4176 (Figure 2). This PSA decline lasted $<4$ weeks and the patient had radiographic disease progression at the time of maximum decrease (59\%) in PSA. No patient had a radiological response. The overall treatment response was determined as progressive disease for 16 patients and stable disease for 6 patients, based on soft tissue and bone scan assessment and clinical impression.

Results for CTCs enumeration were available for 15 patients. Eight patients had $\geqslant 5$ CTCs at baseline and three had a CTC conversion to $<5$ in the first 5 weeks following administration of EZN-4176 with maximum PSA declines of 18 and 26\% in two cases, suggesting a correlation between CTC and PSA decline (see Figure 3). Median duration of treatment in the patients with a CTC conversion was 4.2 months (range 2.3-4.6 months). Seven patients had $<5$ CTCs at baseline and three of them had an increase in 

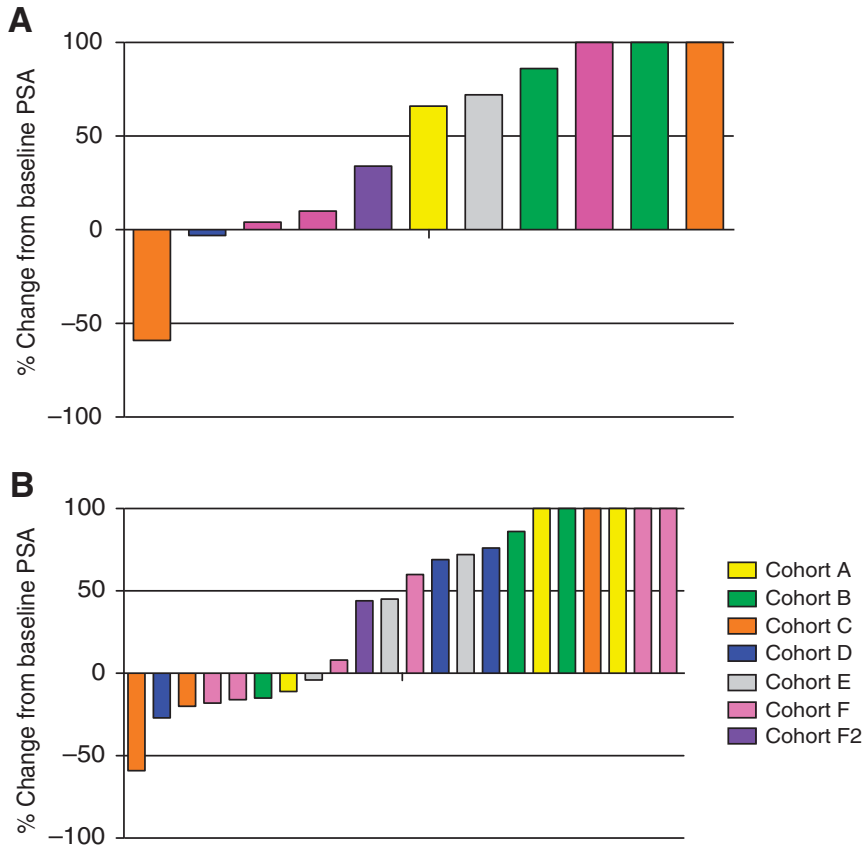

Increases in PSA levels of $>100 \%$ were capped at $100 \%$.

Figure 2. (A) Waterfall plot showing percentage PSA change from baseline at 12 weeks ( $N=11$ evaluable patients). Coloured bars represent individual patients and colours correspond to the dose of EZN-4176. Increases in PSA were capped at 100\%. (B) Waterfall plot showing percentage PSA change from baseline at any time on study $(N=22)$. Coloured bars represent individual patients and colours correspond to the dose of EZN-4176. Increases in PSA were capped at $100 \%$.

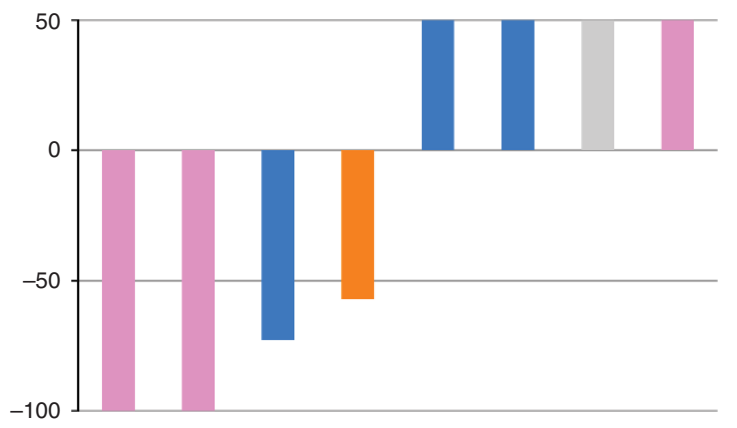

\begin{tabular}{|l|c|c|c|c|c|c|c|c|}
\hline Baseline CTC count & 8 & 7 & 11 & 14 & 9 & 10 & 92 & 97 \\
\hline Best response & 0 & 0 & 3 & 6 & 18 & 25 & 563 & 788 \\
\hline
\end{tabular}

Increases in PSA levels of $>100 \%$ were capped at $100 \%$.

Figure 3. Waterfall plot showing percentage CTC count change from baseline at any time on study in patients with a baseline CTC count of $\geqslant 5(N=8)$. The absolute CTC count at baseline and best response are indicated for each patient in the table. Coloured bars represent individual patients and colours correspond to the dose of EZN-4176 (see Figure 2). Increases in CTC counts were capped at $50 \%$.

CTC count to $\geqslant 5$ CTCs while on trial. The remaining four had $<5$ CTCs throughout.

Two patients had tumour biopsies on-treatment; however, in the first patient, treated in cohort E, the on-treatment biopsy did not contain a tumour. In the second patient, treated in cohort F2, IHC showed no significant AR depletion $24 \mathrm{~h}$ post dose on cycle 1 day 16 compared with the pretreatment sample (see Figure 4 ). The study was terminated due to toxicity and lack of activity in phase $\mathrm{Ia}$, therefore no patients were recruited in Phase Ib.

\section{DISCUSSION}

To our knowledge, this is the first report regarding the use of a third-generation LNA-ASO in patients with advanced prostate cancer. This phase I trial evaluated EZN-4176, a novel LNA-ASO to the AR. Although treatment with EZN-4176 was generally well tolerated at doses up to $6.5 \mathrm{mg} \mathrm{kg}^{-1}$. The observed DLTs with abnormal liver function tests at $10 \mathrm{mg} \mathrm{kg}^{-1}$ on the QW schedule limited further dose escalation. The antitumor activity observed at the dose levels and schedules explored in this study did not warrant further clinical exploration at this time. The failure to demonstrate meaningful antitumour activity may have been due to delivering insufficient doses to achieve the required AR inhibition. Transaminase elevations prevented further dose escalation in the QW schedule. Alternatively, the compound may not have entered the cells effectively.

EZN-4176 was designed as an LNA-ASO to bind specifically within the hinge region of the AR mRNA in exon 4 and to thereby downregulate AR expression (Zhang et al, 2011). It was hoped that this approach would lead to downregulation of not only wild-type and mutant AR but also some AR splice variants. Preclinical studies demonstrated potent down-modulation of AR mRNA and protein in LNCaP and 22Rv1 prostate cancer cell lines (Sapra et al, 2009). However, evaluation of AR using an N-terminal-directed antibody in an on-treatment biopsy from one patient showed no evidence of significant AR knockdown. The timing of this biopsy may not have been optimal to observe AR downregulation but preclinical evidence suggested that downregulation of AR mRNA was sustainable for $72 \mathrm{~h}$ following ENZ-4176 treatment (Zhang et al, 2011; \#136).

The 2-O-methoxyethylribose (MOE) modification as used in second-generation oligonucleotides results in resistance to nuclease degradation and potentially improved activity. Locked-antisense ASO such as EZN-4176 include biochemical modifications to further increase nuclease stability and increased hybridisation affinity (Mansoor and Melendez, 2008). In preclinical mouse models, the comparison with of MOE-ASO with a third-generation LNA-ASO showed increased antitumour activity of LNA-ASO but also severe hepatotoxicity with increased levels of aminotransferases (ALT, AST) and large swelling of liver and spleen (Swayze et al, 2007). It was hypothesised that LNA-ASO could bind to currently unknown macromolecular binding partners and therefore result in compartmentalisation, especially in the liver.

Other LNA-ASOs are in development for specific cancer targets, such as hypoxia-inducible factor $1 \alpha(\mathrm{EZN}-2968)$ and survivin (EZN-3042). Phase I clinical trial data of EZN-2968 in advanced cancer patients reported good tolerability and minimal hepatic toxicity (Patnaik et al, 2009; Cohen et al, 2011). Another phase I trial in patients with advanced cancer and metastatic spread to the liver was recently completed (NCT00466583). A phase I clinical trial of EZN-3042 in children with lymphoblastic leukaemia has been completed (NCT01186328) and another Phase I clinical trial of EZN-3042 in alone or in combination with docetaxel reported only minimal hepatic toxicity (Tolcher et al, 2011).

Second-generation ASOs that form stable complexes with RNA are in late-stage clinical development in prostate cancer. OGX-011 (custirsen, OncoGenex Pharmaceuticals, Bothell, WA, USA), an MOE-modified ASO, inhibits the expression of clusterin, an antiapoptotic protein associated with treatment resistance. A phase I clinical trial was conducted in patients with localised prostate cancer patients. Polymerase chain reaction and immunohistochemistry demonstrated dose-dependent decreases in clusterin 
A
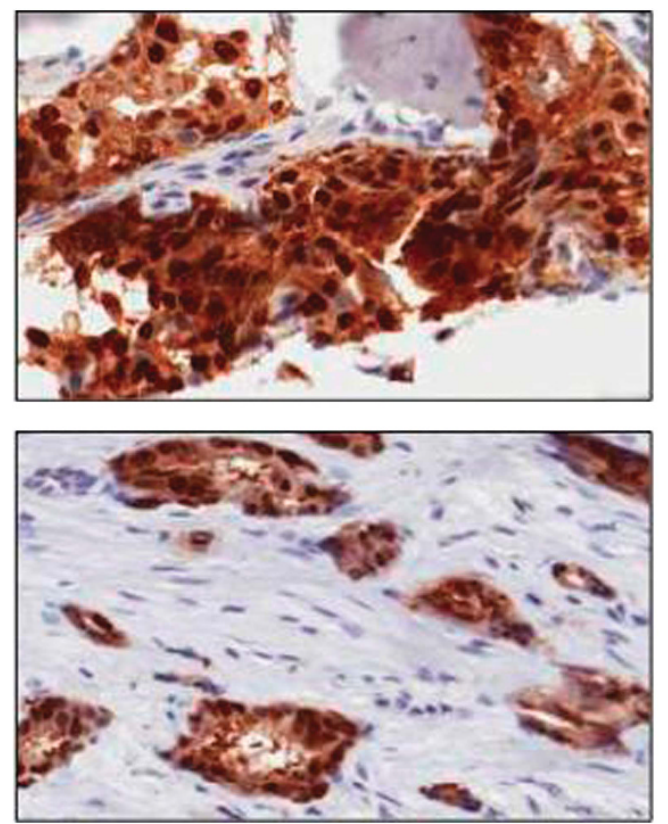

B
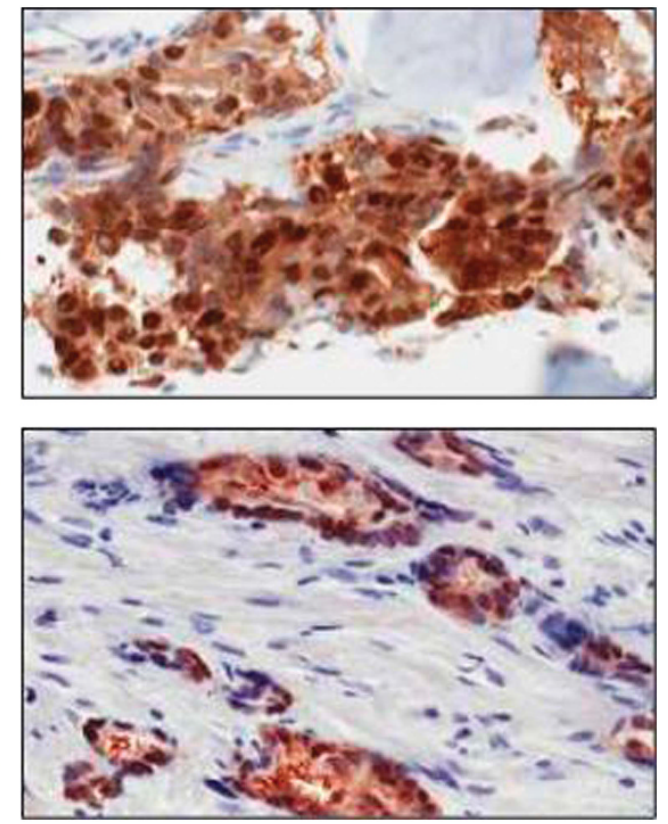

Figure 4. Expression of AR in tumour before EZN-4176 (top) treatment and $24 \mathrm{~h}$ after dosing on cycle 1 day 16 (bottom). No significant AR depletion was observed. AR antibody targeting the amino terminus (A) and carboxy terminus domain (B) of AR.

expression within prostate cancer cells and lymph nodes (Chi et al, 2005). OGX-011 in combination with docetaxel was tested against docetaxel alone in a randomised phase II clinical trial of 82 patients and showed an overall survival benefit of 23.8 months for the combination vs 16.9 months for docetaxel alone (Hazard ratio 0.61, 95\% confidence interval $0.36-1.02$ ) and was generally well tolerated (Chi et al, 2010). Two large randomised phase III trials of clusterin in combination with docetaxel (NCT01188187) or cabazitaxel (NCT01578655) are ongoing and will define the role of second-generation ASOs in prostate cancer. Further secondgeneration ASOs are in earlier-stage development, namely OGX427, an ASO targeting Hsp27 (Chi et al, 2012).

Preclinical testing of future LNA-ASO will need to include predictors of hepatic toxicity such as hepatic microsome or animal models (Hengstler et al, 2000; Swayze et al, 2007; Moeller et al, 2012).

Development of compounds targeting the AR and in particular the amino-terminal domain, which would result in the downregulation of both full-length and splice variant $A R$, remains a key priority. Expression of AR splice variants has been associated with resistance to abiraterone and enzalutamide in preclinical models (Mostaghel et al, 2011; Li et al, 2013). Furthermore, AR mutations that render enzalutamide or AR-509 into AR agonists have been described (Balbas et al, 2013). Translational evidence of continued $\mathrm{AR}$ activation in patients progressing on abiraterone or enzalutamide opens possibilities of testing new LNA-ASOs in this population.

In summary, the activity of EZN-4176 at the doses and schedules explored was minimal. The highest dose of $10 \mathrm{mg} \mathrm{kg}^{-1}$ QW was associated with significant but reversible transaminase elevation. The current study was halted at the Phase 1a stage for business reasons.

\section{ACKNOWLEDGEMENTS}

We acknowledge the pharmacokinetics work performed by DUCK FLATS Pharma, LLC; P.O. Box 101, 245 East Main Street, Elbridge,
NY 13060, namely Luana Pesco Koplowitz, MD, PhD and Barry Koplowitz, MS. This trial was sponsored by Enzon pharmaceuticals. The authors from the Prostate Cancer Targeted Therapy Group are employees of the Section of Medicine that is supported by a Cancer Research UK programme grant an Experimental Cancer Medical Centre (ECMC) grant from Cancer Research UK and the Department of Health (Ref: C51/A7401), by the Prostate Cancer Foundation (PCF), by Experimental Cancer Medicine Centre initiative ECMC and by the NIHR Biomedical Research Centre (BRC). GA is supported by a Cancer Research UK Clinician Scientist Fellowship. The authors acknowledge NHS funding to the Royal Marsden NIHR Biomedical Research Centre. $\mathrm{AO}$ is recipient of a 2-year bursary from the Swiss Cancer League (No. BIL KLS-02592-02-2010).

\section{CONFLICT OF INTEREST}

JSdB received consulting fees from Enzon. AB is employee of Enzon pharmaceuticals. HS reports consulting with Aragon Pharmaceuticals (U), Enzon Pharmaceuticals (C), Exelixis Inc. (U), Johnson and Johnson Pharmaceutical \& Development, LLC (U), Medivation (U), Millennium (C), Orion-Endo Pharmaceuticals (C), and Veridex (U) (a Johnson \& Johnson Company), grant support to Memorial Sloan-Kettering Cancer Center from Aragon Pharmaceuticals, Exelixis, Medivation, Janssen Research \& Development LLC, Janssen Services, Inc, Medivation and Veridex. $(\mathrm{C})=$ Compensated; $(\mathrm{U})=$ Uncompensated.

\section{REFERENCES}

Attard G, Richards J, de Bono JS (2011) New strategies in metastatic prostate cancer: targeting the androgen receptor signaling pathway. Clinical Cancer Res 17(7): 1649-1657.

Balbas MD, Evans MJ, Hosfield DJ, Wongvipat J, Arora VK, Watson PA, Chen Y, Greene GL, Shen Y, Sawyers CL (2013) Overcoming mutationbased resistance to antiandrogens with rational drug design. Elife 2: e00499. 
Chi KN, Eisenhauer E, Fazli L, Jones EC, Goldenberg SL, Powers J, Tu D, Gleave ME (2005) A phase I pharmacokinetic and pharmacodynamic study of OGX-011, a 2'-methoxyethyl antisense oligonucleotide to clusterin, in patients with localized prostate cancer. J Natl Cancer Inst 97(17): 1287-1296.

Chi KN, Hotte SJ, Ellard S, Gingerich JR, Joshua AM, Yu EY, Gleave ME (2012) A randomized phase II study of OGX-427 plus prednisone (P) versus $\mathrm{P}$ alone in patients (pts) with metastatic castration resistant prostate cancer (CRPC). J Clin Oncol 30: (suppl; abstr 4514).

Chi KN, Hotte SJ, Yu EY, Tu D, Eigl BJ, Tannock I, Saad F, North S, Powers J, Gleave ME, Eisenhauer EA (2010) Randomized phase II study of docetaxel and prednisone with or without OGX-011 in patients with metastatic castration-resistant prostate cancer. J Clin Oncol 28(27): 4247-4254.

Cohen RB, Olszanski A, Figueroa J, Hurwitz H, Lokiec FM, Rezaï K, Berkowitz N, Buchbinder A (2011) Down-modulation of messenger ribonucleic acid ( $m R N A$ ) by EZN-2968, an hypoxia-inducible factor-1 alpha (HIF-1alpha) mRNA antagonist, administered in adult patients with advanced solid tumors. AACR: Orlando, FL, USA, April 5, 2011.

de Bono JS, Logothetis CJ, Molina A, Fizazi K, North S, Chu L, Chi KN, Jones RJ, Goodman Jr. OB, Saad F, Staffurth JN, Mainwaring P, Harland S, Flaig TW, Hutson TE, Cheng T, Patterson H, Hainsworth JD, Ryan CJ, Sternberg CN, Ellard SL, Flechon A, Saleh M, Scholz M, Efstathiou E, Zivi A, Bianchini D, Loriot Y, Chieffo N, Kheoh T, Haqq CM, Scher HI (2011) Abiraterone and increased survival in metastatic prostate cancer. N Engl J Med 364(21): 1995-2005.

Dehm SM, Tindall DJ (2011) Alternatively spliced androgen receptor variants. Endocr Relat Cancer 18(5): R183-R196.

Gleave ME, Monia BP (2005) Antisense therapy for cancer. Nat Rev Cancer 5(6): 468-479.

Guo Z, Yang X, Sun F, Jiang R, Linn DE, Chen H, Chen H, Kong X, Melamed J, Tepper CG, Kung HJ, Brodie AM, Edwards J, Qiu Y (2009) A novel androgen receptor splice variant is up-regulated during prostate cancer progression and promotes androgen depletion-resistant growth. Cancer Res 69(6): 2305-2313.

Hengstler JG, Utesch D, Steinberg P, Platt KL, Diener B, Ringel M, Swales N, Fischer T, Biefang K, Gerl M, Bottger T, Oesch F (2000) Cryopreserved primary hepatocytes as a constantly available in vitro model for the evaluation of human and animal drug metabolism and enzyme induction. Drug Metab Rev 32(1): 81-118.

Li Y, Chan SC, Brand LJ, Hwang TH, Silverstein KA, Dehm SM (2013) Androgen receptor splice variants mediate enzalutamide resistance in castration-resistant prostate cancer cell lines. Cancer Res 73(2): 483-489.

Linja MJ, Savinainen KJ, Saramaki OR, Tammela TL, Vessella RL, Visakorpi T (2001) Amplification and overexpression of androgen receptor gene in hormone-refractory prostate cancer. Cancer Res 61(9): 3550-3555.

Mansoor M, Melendez AJ (2008) Advances in antisense oligonucleotide development for target identification, validation, and as novel therapeutics. Gene Regul Syst Biol 2: 275-295.

Moeller TA, Shukla SJ, Xia M (2012) Assessment of compound hepatotoxicity using human plateable cryopreserved hepatocytes in a 1536-well-plate format. Assay Drug Dev Technol 10(1): 78-87.

Montgomery RB, Mostaghel EA, Vessella R, Hess DL, Kalhorn TF, Higano CS, True LD, Nelson PS (2008) Maintenance of intratumoral androgens in metastatic prostate cancer: a mechanism for castration-resistant tumor growth. Cancer Res 68(11): 4447-4454.

Mostaghel EA, Marck BT, Plymate SR, Vessella RL, Balk S, Matsumoto AM, Nelson PS, Montgomery RB (2011) Resistance to CYP17A1 inhibition with abiraterone in castration-resistant prostate cancer: induction of steroidogenesis and androgen receptor splice variants. Clinical Cancer Res 17(18): 5913-5925.
Patnaik A, Chiorean EG, Tolcher A, Papadopoulos K, Beeram M, Kee D, Waddell M, Gilles E, Buchbinder A (2009) EZN-2968, a novel hypoxiainducible factor- $1 \alpha$ (HIF- $1 \alpha$ ) messenger ribonucleic acid (mRNA) antagonist: Results of a phase I, pharmacokinetic (PK), dose-escalation study of daily administration in patients (pts) with advanced malignancies. J Clin Oncol 27(15s) (suppl; abstr 2564).

Richards J, Lim AC, Hay CW, Taylor AE, Wingate A, Nowakowska K, Pezaro C, Carreira S, Goodall J, Arlt W, McEwan IJ, de Bono JS, Attard G (2012) Interactions of abiraterone, eplerenone, and prednisolone with wild-type and mutant androgen receptor: a rationale for increasing abiraterone exposure or combining with MDV3100. Cancer Res 72(9): 2176-2182.

Ryan CJ, Smith MR, de Bono JS, Molina A, Logothetis CJ, de Souza P, Fizazi K, Mainwaring P, Piulats JM, Ng S, Carles J, Mulders PF, Basch E, Small EJ, Saad F, Schrijvers D, Van Poppel H, Mukherjee SD, Suttmann H, Gerritsen WR, Flaig TW, George DJ, Yu EY, Efstathiou E, Pantuck A, Winquist E, Higano CS, Taplin ME, Park Y, Kheoh T, Griffin T, Scher HI, Rathkopf DE (2013) Abiraterone in metastatic prostate cancer without previous chemotherapy. N Engl J Med 368(2): 138-148.

Sapra P, Zhang Y, Castaneda S, Kim S, Kraft P, Bandaru R, Greenberger LM, Hora ID (2009) A locked nucleic acid antisense oligonucleotode against androgen receptor, down-modulates target $m R N A$ and causes antitumor effects in xenograft models of prostate cancer. AACR-NCI-EORTC International Conference: Molecular Targets and Cancer Therapeutics, Boston, MA, USA, Abstract C144.

Scher HI, Fizazi K, Saad F, Taplin ME, Sternberg CN, Miller MD, de Wit R, Mulders P, Chi KN, Shore ND, Armstrong AJ, Flaig TW, Flechon A, Mainwaring P, Fleming M, Hainsworth JD, Hirmand M, Selby B, Seely L, de Bono JS (2012) Increased survival with enzalutamide in prostate cancer after chemotherapy. N Engl J Med 367(13): 1187-1197.

Scher HI, Halabi S, Tannock I, Morris M, Sternberg CN, Carducci MA, Eisenberger MA, Higano C, Bubley GJ, Dreicer R, Petrylak D, Kantoff P, Basch E, Kelly WK, Figg WD, Small EJ, Beer TM, Wilding G, Martin A, Hussain M (2008) Design and end points of clinical trials for patients with progressive prostate cancer and castrate levels of testosterone: recommendations of the Prostate Cancer Clinical Trials Working Group. J Clin Oncol 26(7): 1148-1159.

Swayze EE, Siwkowski AM, Wancewicz EV, Migawa MT, Wyrzykiewicz TK, Hung G, Monia BP, Bennett CF (2007) Antisense oligonucleotides containing locked nucleic acid improve potency but cause significant hepatotoxicity in animals. Nucleic Acids Res 35(2): 687-700.

Tolcher AW, Amita Patnaik A, Papadopoulos KP, Agnew J, Lokiec FM, Rezaï K, Stacey Kalambakas S, Buchbinder A (2011) Results of a Phase 1, open-label, dose-escalation study evaluating the safety and tolerability of EZN-3042, a survivin messenger ribonucleic acid (mRNA) antagonist, administered with or without docetaxel in adult patients with advanced solid tumors or lymphoma. AACR: San Francisco, CA, USA, November 13, 2011.

Vidal L, Blagden S, Attard G, de Bono J (2005) Making sense of antisense. Eur J Cancer 41(18): 2812-2818.

Zhang Y, Castaneda S, Dumble M, Wang M, Mileski M, Qu Z, Kim S, Shi V, Kraft P, Gao Y, Pak J, Sapra P, Bandaru R, Zhao H, Vessella RL, Horak ID, Greenberger LM (2011) Reduced expression of the androgen receptor by third generation of antisense shows antitumor activity in models of prostate cancer. Mol Cancer Ther 12: 2309-2319.

This work is published under the standard license to publish agreement. After 12 months the work will become freely available and the license terms will switch to a Creative Commons AttributionNonCommercial-Share Alike 3.0 Unported License. 